\title{
DISABILITY THEATRE MANIFESTO
}

\author{
By Emily Gray
}




\section{FOREWORD}

- Situate myself as an ally

- Purpose of this work is not to look for 'best' practices, but rather 'better' practices

- Two perspectives in disability theater academia:

- Benefits and idealistic thinking in purple

- Drawbacks and realistic thinking in red 


\section{CONSIDERATION OF INACCESSIBILITY OF MAINSTREAM THEATRE}

- Theatre is oriented toward normates:

- Normate spaces

- Normate time

- Normate languages 


\section{DECONSTRUCTING 'DISABLED’}

\section{Drawbacks:}

- The word 'disabled' creates otherness

- Biological metaphors attached to binary structure

- Women viewed as 'less rational

- Black people viewed as more 'animal-like'

- Disabled people aligned with disease, poverty, degeneracy, tragedy, loss and victimhood

- Able-bodied people thinking disabled people want to be 'normal'

- Undermines positive experiences of disability culture 


\section{DECONSTRUCTING 'DISABLED’}

\section{Benefits:}

- Claiming disability means access to accommodations (pain killers, disabled parking plates, etc

- Reclaiming the word

- Source of communality and cohesion in the face of oppression 


\section{ACKNOWLEDGMENT OF WHAT DISABILITY THEATRE ONCE WAS}

- 'Freak Shows'

- Managers had more rights to the bodies of performers than the performers did themselves

- Pitchmen enticing in with exaggerations of strangeness

- Hyperbolizing environments

- Memorabilia

- Disabled people performing mundane tasks 


\section{WHAT IS DISABILITY THEATRE NOW?}

- Artists who feel a strong connection between their disability and their art who see themselves as part of the disability movement

- Moving from medical model to social model

- Different approaches:

- Radical vs subtle

- Seeking charitable status vs rejecting charitable status

- Exclusively disabled vs mixed ability groups 


\section{WHO CAN PLAY WHAT ROLE?}

- Spectrum of belief over who can play what role

- Is problematic representation better than no representation at all?

- Push for able-bodied actors to refuse disabled roles

-Would that mean that the roles would just disappear?

- Having a hard time finding disabled talent is no excuse

- Disabled bodies onstage is necessary so that they become less of a rarity - leads to recognizing humanity 


\section{DISCLOSURES}

- "What happened to you?"

- Choosing to answer question

- Opportunity of self-definition

- Opportunity to educate on ableism

- Pandering to able-bodied audience?

- Choosing not to answer

- Power in refusing to explain - one's body does not require explanation

- Non-visibly disabled disclosures

- If they do not disclose, a part of the disabled community is not represented

- Why should they have to disclose? 


\section{WHY AREN'T MORE DISABLED PEOPLE GOING INTO THE ARTS?}

- Barriers to full course loads

- STEM jobs more appealing

- Actor training dissuading students

- Neutral body

- Emotional body 


\section{CALLS TO ACTION}

- For those employed by the university:

- Consider what more you could be doing!

- Visit Disability Services!

- Make a recruitment plan for disabled students!

- You have a lot of power - use it! 


\section{CALLS TO ACTION}

- For everyone:

- Go and support disability theatre! 


\section{CALLS TO ACTION}

- For everyone:

- Go and support disability theatre!

Most importantly...

HOLD YOURSELVES AND OTHERS RESPONSIBLE!

HOLD YOURSELVES AND OTHERS RESPONSIBLE!

HOLD YOURSELVES AND OTHERS RESPONSIBLE!

USE THE INFORMATION PRESENTED TODAY AND LET IT INFLUENCE YOUR FUTURE ACTIONS! 


\section{BIBLIOGRAPHY}

Abbas, Jihan, Kathryn Church, Catherine Frazee, and Melanie Panitch. "Lights ...Camera ... Attitude! Introducing Disability Arts and Culture." Ryerson rbc Institute for Disability Studies Research and Education (2004): I-58, 13 May 2007. http://www.ryerson.ca/ds/pdf/artsreport.pdf.

Arts Smarts: Inspiration and Ideas for Canadian Artists with Disabilities. Vancouver: Society for Disability Arts and Culture, 2002.

Barnes, Colin, and Geof Mercer. Disability. Cambridge: Polity, 2003.

Bulmer,Alex.“Inclusion: Building a Culture of Desire and Resilience.” Theatre Research in Canada. 37.2 (2016). Print.

Dokumaci,Arseli. “Affordance Creations of Disability Performance: Limits of a Disabled Theater.” Theatre Research in Canada. 37.2 (2016). Print.

Doolittle, Lisa, et al. "May I have this dance? Teaching, Performing, and Transforming in a University-Community Mixed Ability Dance Theatre Project." Theatre Research in Canada. 37.2 (2016). Print.

Fox,Ann M. "How to Crop the Undergraduate Classroom: Lessons from Performance, Pedagogy, and Possibility." Journal of Postsecondary Education and Disability. 23.1 (2010): 38-47. Print.

Fraser, Brad. Kill Me Now.Toronto: Playwrights Canada Press, 20I5. Print. 


\section{BIBLIOGRAPHY (CONTINUED)}

Garland-Thomson, Rosemarie. Extraordinary Bodies: Figuring Physical Disability in American Culture and Literature. New York: Columbia University Press, 1997. Print.

-. Staring: How We Look. London: Oxford UP, 2009. Print.

-."Staring Back: Self-Representations of Disabled Performance Artists.” American Quarterly 52.2 (2000): 334-48. Print.

Johnston, Kirsty. Stage Turns: Canadian Disability Theatre. Montreal and Kingston, ON: McGill-Queen's UP, 20I2. Print.

Kuppers, Petra."Crip Time.” Tikkun: to heal, repair, and transform the world. tikkun.org 20 Oct. 20I4.Web. 10 Mar. 2018.

-. Disability and Contemporary Performance: Bodies on Edge. London and New York: Routledge, 2003. Print.

Lewis,Victoria. Beyond Victims and Villains: Contemporary Plays by Disabled Playwrights. New York:Theatre Communications Group, 2006. Print.

Mairs, Nancy. “On Being a Cripple.” In Nancy Mairs, Plaintext: Essays. Tucson, Ariz: University of Arizona Press, 1986, pp. 9-2I.

McNish, Deric. "The 19 percent: Disability and Actor Training in Higher Education.” Diss. U of Colardo, Department of Philosophy. 2013. Print.

Sandahl, Carrie. "The Tyranny of Neutral: Disability \& Actor Training." Bodies in Commotion: Disability and Performance. Ed. Carrie Sandahl and Philip Auslander.Ann Arbor:The U of Michigan P, 2005. 255-267. Print.

Zien, Katherine. “A Mobile Social Realm: Labour, Sovereignty, and Subjecthood in Disabled Theater." Theatre Research in Canada. 37.2 (2016). Print. 